of the whole life and not merely of some portion of it; any. thing, therefore, which tends to unfit the missionary for service is a real, although an unintentional, disloyalty, and the acceptance by missionaries on furlough of any work or responsibility that interferes with their recuperation is to be deprecated. In this connexion it is necessary for the society also to exercise a wise care and discretion. In the eagerness of desire to kindle enthusiasm and to diffuse a knowledge of mission work, the organizing secretary is sometimes too anxious to get as much deputation and meeting work as possible out of the returned missionary. Individuals vary greatly in their capacity for this work, and while to one it is a pleasure and inspiration, to another it is a great ordeal and one that seriously interferes with health. As a general rule it may be taken that no returned missionary should be asked to take deputation work of any kind for the first three months after arrival; more especially is this necessary in the case of the wife and mother. It is difficult to realize the amount of wear and tear that a good housewife and mother has to undergo; the daily vigilance over family and household; the frequently recurring anxieties inseparable from family life in the tropics; and in some instances the annoyances inherent in the manage. ment of native servants and others, conspire to wear le: out and $t, \mathrm{~b}$ break down her nervous system. Such a woman requires all the available time of her furlough to build up her health and recover her strength so that she may be fit to return with her husband to the field. These, then, are the reasons why the medical adviser should carefully inquire isto $h \mathrm{~m}_{3}$ circumstances, and as to how the wearied missionary proposes to spend her holiday. He should tactfully and sympathetically indicate that the object of her furlough is not that she should relieve some other over-burdened member of her family, nor that she should constitute herself sick nurse and guardian, but that she should in the first instance do her duty to her socicty, her husband, and herself.

Not infrequently the medical adviser will find that his patient is a worn ard delicate woman with five or six litt'e children, and that, thankful as she is to have the prospect of a better climate, she is somewhat nervous and doubtful of her power to cope with the active healthy little ones without the help of the servants to whom she lias naturally been accustomed in the tropics. Native ayahs and bearers need a great deal of supervision, but they are, at any rate, hands and feet, and they are very generally lind and devoted to their little charges, but the English home of the returned missionary is frequently all too small, and the service leaves much to be desired; consequently, the children are much with their parents, and the tired mother spends a great part of her much-needed holiday in washing and dressing the children, in sewing for them, and even in wheeling the perambulator for one or two, while others liang on to her skirt. It would really appear as though some guild or association should be formed to afford help under such conditions. The parents would not like to part with their little ones, but it might perhaps be possible for young ladies gifted with missionary zeal to form them. selves into a guild of help, the members of which would be available to live with each missionary family and assist in the care of the children. An alternate scheme might be the collection of a spccial fund for increasing the missionaries' incomes during furlongh, so as to enable them to make their own arrangements for such assistance as they found necessary.

Before the return to the field the married woman missionary should be seen by the society's medical adviser, who should be satisfied as to her fitness for return, and enter on the health sheet any observations that may be necessary.

The Henry Saxon Snell Prize will be awarded this year by the council of the Roral Sanitary Institute for an essay on "Suggestions for Improvements in the Sanitary Arrangements and Appliances suitable on Board ship for (a) Passengers and Crew, (b) Cattle and other Live Stock." it consists of 50 guineas and the silver medal of the institute. The essay, which must not exceed 5,000 words in length, is to be typewritten on foolscap, one side only, and to be illustrated by drawings or sketches. Essays inust be delivered on or before November 1st, 1915, addressed to the Secretary of the Royal Sanitary Institute, 90, Buckingham Palace Road, London, S.W.

\section{TRAUMATISM AND TUBERCULOSIS.}

SIR THOMAS OLIVER, M.D., F.R.C.P. PROFFSSOR OF THE PRINCIPLES AND PRACTICE OF MEDICINE, DNIVERSITY OF DCRIAM COI,LEGE OF MEDICINE.
NETCASTLE-UPON-TYNL.

IT is now several years since my attention was first directer to the relation of injury of the chest wall to pulmonary tuberculosis.

A healthy girl, aged 17, while crossing a street in Newcastle, had been knocked down by a cab. Her chest was injured, but no ribs were broken. An hour or so after the accident she had haemoptysis. When I examined her, three months after the accident, there were signs of advancing pulmonary phthisis;
cavitation was limited to the right apex, the side of the chest which had been injured. She gradually but quickly emaciated which had been injured. She gradually but quickly emaciated, cough became more frequent, accompanied by muco-purulent
expectoration, and haemoptysis kept recurring from time to expectoration, and haemoptysis kept recurring from time
time. Death came within two months of my first seeing her.

On the occasion of her first visit I was struck by the fact that a girl, said to have been quite healthy until the day of the accident, should show so sliortly after the injury signs of pronounced phthisis. Since then several similar cases have come under my observation, and are not without interest from the point of view of the liability of employers for accidents under the Workmen's Compensation Act. The subject of traumatism and tuberculosis is, therefore, one upon which it is well for all of us to hare a definite opinion.

Eighteen months ago a mason's labourer, who had never lost time through illness, fell from a scaffolding a distance of $6 \mathrm{ft}$. injuring his right lip and chest against a brick wall. Little was thought of the injury at the time. The man at the close of the day's work walked a short distance to a railway station and travelled by train home. Nine days after the injury he had haemoptysis. From this he recovered and returned to work. Six weeks after the accident he complained of pain in the right chest. On examination, a doctor found evidence of pleurisy with effusion. Despite treatment the patient gradually got worse. He emaciated rapidly. Within few months he lost 4 st, in weight, cough became Within a quent, and expectoration more fre quent, and expectoration more abundant, while in the sputum myriads of tubercle bacilli were found. When I first saw hin there was considerable dullness over the base of the right lung,
but on an exploratory puncture being made no fluid was found. There were signs of rapidly advancing disease in the apex of There were signs of rapidly advancing disease in the apex of
the right lung. $A \mathrm{~s}$ the workman claimed damages from his the right lung. As the workman claimed damages from his
employer, the case was heard in the county ccurt. The patient. employer, the case was heard in the county ccurt. The patient, who was awarded full compensation on the ground that the
pulmonary disease was the consequence of the accident, lived only a month or two after receiving the verdict in his favour.

While penning these notes I had ander my care in the Roya Victoria Infirmary a miner who, when emptying a railway wagon, fell over the side of the wagon, bruising his right che against the grease-box. Within two hours after the accildn he had haemoptysis, but notwithstanding this he continued at work a few hours longer. That evening he did not sleep well; he was restless. Next morning the bleeding returned and continued for four days. Cough subseguently developed with con of pulmon of pulmonary disease, accompanied by the presence of tubercle bacillin the sputum. Cavitation of the apex of the right lnne occurred, and while at the thme these notes were witen the patient was progressing satisfactorily under the open-air treatafterwards from advanced pulmonary tuberculosis.

How are we to connect the fact of injury to the chest wall of a previously healthy person with subsequent tuberculosis? The lung disease so clearly and definitely follows the injury that there must be some connexiou between the two. It is not only in affections of the lungs that the sequence of tuberculosis to injury is observed; it is seen also in affections of the joints and bones, the interesting fact being that frequently the accident is said to have been of such a slight nature as not to havo attracted the attention of the patient or his friends at tho time. In nearly all the instances of pulmonary tuberculosis following injury which have come under my care the injury has been of a serious nature. A sign that tho lungs had suffered was haemoptysis occurring an hour or two after the accident. In some patients the bleeding did not show itself until two cr three days after the accident; in the case of the mason's labourer reported, bleeding did not take place until the ninth day, but whether haemoptysis occurred early or late the after-events wcro the same in all, namely, pulmonary tuberculosis running rapidly to a fatal termination.

MM. Georges Brouardel and Leon Giroux ${ }^{1}$ state that Jeannel found 5.5 per cent. of the cases of tuberculosis 
under his care post-traumatic; Wilner 6 to 7 ; Pietrzikowski 8; Hahn found that 13 per cent. of his cases of tuberculous disease of the ankle were post-traumatic; König 20 per cent. of diseased knee-joints, while Horzetsky obtained a traumatic history in 44 per cent. of diseased spines. Bronarcel and Giroux state that of 30 cases of injury to the chest they had examined which became tuberculous, in only 2, that is, 6.6 per cent., did they admit the possibility of such a causal relationship. In Germany Demme found in 159 patients suffering from wounds of the lungs caused by bullets that 17 subsequently developed tuberculosis.

Bleeding from the lung occurring shortly after injury to the chest wall and followed by pulmonary tuberculosis raises the question, Is there such a malady as phthisis ab haemoptoe? Experiments have been made by opening the trachea of animals and injecting healthy blood into the bronchial tubes. If the animals were subsequently kept in a warm atmospliere they recovered without any bad effects, the blood was absorbed and no lesion was found in the lungs; but if, after the operation, the animals were allowed to run about in the open air exposed to cold and wet, an alveolar catarrh developed, and the lungs became the seat of a low form of inflammation. The presence of free blood in the pulmonary alveoli and in the small bronchi thus became the starting-point of pulmonary disease. By the presence of blood in the lungs local resistance becomes reduced and the organs a possible prey to all kinds of micro-organisms, including the tubercle bacillus.

When haemorrhage occurs after injury to the chest wall, what is the cause of the bleeding? If blood was spat up immediately, it might probably be attributed to almost direct injury to the pulmonary blood ressels, but usually haemoptysis does not occur until one, two, or several hours, or even a few days after the accident. The delay in its appearance and the manner in which it recurs suggest that there probably had been some pre-existing disease-some latent focus in the lung-and that, as a resuit of the contusion, pulmonary tissue which had undergone structural change had become more friable, and was therefore easily torn.

Before attempting to reply to the further question whether there is a true traumatic pulmonary tuberculosis, let us see what experiment can tell us. In $1878 \mathrm{Max}$ Schüller injected human tuberculous expectoration into the lungs of dogs and rabbits, and he then caused to be sprained or otherwise injured the knee-joints of these animals, with the result that in nearly all of them there developed a granular inflammation of the joints with structural changes in the cartilage and underlying bone, while in control healthy animals the same injuries provoked no iesion at all. To the injured joints, therefore, of infected animals tubercle bacilli and other micro-organisms found their way; in other words, while simple injury per se did little or no harm to a joint, it was quite otherwise if there were present at the same time infective micro-organisms within the body, for these became attracted to the injured part. Lannelongue and Achard placed tuberculous material under the skin of 20 guinea-pigs, and, after giving sufficient time for infection to have occurred, some of the joints of the animals were subjected to injury. All the animals died from tuberculosis, but not in one of them did the joints which had been injured show signs of tubercle. According to Lannelongue and Achard, it is not easy to induce a tuberculous process at the seat of injury. In this field of inquiry Petrow also carried out a series of experiments. He first injured the joints and thereafter injected into them tuberculous material. The experiment was repeated upon uninjured lealthy joints. In those animals whose joints had nct been injured the lesions were limited to the ligaments and capsule, but in those whose joints were injured previously to the injection of tuberculous material, the continuity of the cartilages was destroyed, while here and there a few small tuberculous nodules could be seen. Petrow took other 18 rabbits, injected into their veins human tuberculous material, and afterwards caused in those 18 animals 18 intra-articular fractures, 18 sprains, and 18 slight contusions. At the end of $3 \frac{1}{1}$ months the animals were dead. They all showed signs of tuberculosis. Of the 18 joints which had been injured 11 were tuberculous; of those which had been slightly contused 2 were tuberculous, while of those which had not been injured 2 were tuberculous. Reviewing Petrow's experiments, it may be said that injury seemed to have had some influence in determining tubercle bacilli to a joint when the disease was already present in the body.

The answer to the question whether there is or is not such a condition as traumatic tubereulosis is not to be obtained from experiment alone, but from experiment and clinical experience. All of us know that many patients who are the subjects of tuberculosis are receiving from time to time minor injuries to their joints and bones, and that those injuries heal quite well. If in these patients, just as in the animals experimented upon by Lannelongue, it is difficult for an injury to create a tuberculous joint, how much more difficult mast it be for an injury to set up a local tuberculosis when people are healthy.

When localized tuberculosis shows itself after an injury inquiry ought to be directed to the previous health of the patient, always bearing in mind that in upwards of 70 per cent. of the post-mortem examinations made in infirmaries upon the bodies of persons who have died, not from tubercnlosis, but from other causes, there are evidences in the lungs of healed or latent tuberculosis, so that should any of these people have received an injury to the chest wall it is possible that at the site of the pulmonary lesion the surrounding lung tissue might hare become lacerated, a haemorrhage might have occurred, and tubercle bacilli, becoming liberated, might have found in their new surroundings fresh pabulum for growth and reproduction. When the chest wall has been injured, the point d'appui is constituted by the column of air retained in the lung through closure of the glottis and not by the blood circu. lating in the lung. Any diseased condition which interferes with the elasticity of the lung would be more likely to be followed by tearing of blood vessels than would bo the case in a healthy lung. Sourdille reports the case of a man who died eight days after having received a kick on the left chest from a horse. No bones were broken. At the autopsy a considerable quantity of sero-sanguinolent fluid was found in the left pleural cavity, false membrane was present on both the visceral and parietal layers of the pleura; atelectasis of the lower lobe of the left lung, with congestion of the upper lobo, were notable features, while at the level of the injury there was a pouch the size of a duck's egg which contained black clotted blood. This pocket in the lung tissue lay underneath the pleura, its walls were irregular, and one bronchus had been torn right across. Had this man survived the injury, there can hardly be any doubt that the lacerated lung would have formed an attractive area for all kinds of microorganisms, including tubercle bacilli.

It is interesting to remember that where death lias followed injury to the chest wall the lung opposite to the side injured has sometimes shown more serious lesions than the lung on the side which had been contused.

Another condition for which medical men are consulted will be best understood if I give an illustration from my own experience:

A working man, previously believed to have been healthy, strained himself when lifting a heavy iron plate. Severe pain at once struck him in the back; he was obliged to sit down partly through pain and partly through a sense of faintness. The following day he brought up a small quantity of blood. The haemoptysis recurred during the next four days. An incomplete recovery toak place. The man returned to his work and followed his employment for some months. When I examined him six months afterwards the lungs were found to be the seat of rapidly advancing phthisis.

Supposing this man's lungs were healthy before the severe muscular strain, was the haemoptysis simply the result of effort, and was the haemoptysis the cause of the pulmonary tubercuiosis which followed? In traumatic pulmonary disease three events follow in due succession -namely, injury to the chest wall or a severe strain, baemoptysis, phthisis. At first sight it would seem as if injury started the morbid process, as if it had been the first link in the chain of morbid events, but can we be quite sure that there was no abnormal condition of the lung anteriorly to the injury? If previous disease can be affirmed, or if it can even be said to have been strongly suspected, is it not the more important circumstance since but for it traumatism could hardly have played the part it did in ultimately giving rise to morbid conditions which led to death? It is hardly conceivable that injurv can 
create a condition of lung so distinctly microbic as that observed in tuberculosis. Where pleurisy has followed injury and become tuberculous, it is just possible the following has taken place: Knowing the high percentage of pleurisies which are tuberculous from the first or become so, it would appear as if a limited patch of tubercle situated under the visceral layer of the pleura hath, as a result of injury to the chest wall, become activated, and the germs from their proximity had infected the pleura, or, as a result of sloock to the system by the injury, the resistance of the body generally and of the lung locally had become reduced, the entrance of the tubercle bacillus into the body favoured, and the way made casier for the devclopment and multiplication of the microbe, whose presence therein would therefore be not a direct sequence of the injury, but simply incidental to it.

'Tubercle bacilii have been found in the blood of persons who have suffered or who have died from tuberculosis. It is thus wo scek to explain the disseminated miliary lesions in acute tubercinlosis. 'The presence of tubercle bacilli in the blood has been shown expermentally and the blood of affected porsons when injected into guinea-pigs has induced in them tubarculosis. Kurashige, a Japanese, found tubercle bacilli not only in tuberculous patients, but taking thirty-four apparently healthy persons he found the micro oganism present in twenty. Within eight months after wihds three of these developed tuberculosis. If we admit that tubercle bacillaemia is a more frecuuent condition than is generally supposed the consequence of injury to the chest wall can be readily imagined.

On this point, howerer, we must not be carried away too nuch by microscopical findings, for acid fast resisting bacilli, closely resembling the specific micro organisms in question, may be found in other conditions than tubercle. 'They are occasionally found, for example, in distilled water. 'l'o remove doubt Ji. Slacle, bacteriologist to the lioyal Victoria Infirmary, Neweastle, and myself carriec ont a series of experiments. We took blood from several patients in all stages of pulmonary consumption, whose expectoration contained tubercle bacilli in large numbers and after following out rigidly the techmique recommended, in none of t.e fiums did we detect well-formed tubercle bacilli. Now and again we found what might have been bacillary débris. Nor was the injection of the blood of affected patients followed by tuberculosis in the guinea pios who received the blood. These circumstances inclicated to us that if tubercle bacilli are present in the blood they are cxtremely fow and thercfore rlifficult to find; in a word, tubercle bacillaemia is not of frequent occurrence.

The relationship of traumatism and tuberculosis may o cxpressed thus: Tuberculosis develops in a person who, until the accident, was believed to be quite healthy; latent tuberculosis is roused into activity by the accident; a tuberculous lesion becomes localized at the site of injury the micro-organisms having been carried thither from a focus elsewhere in the body, or injury has simply aggravated a localized lesion which was previously present. Althongh there is no tuberculosis without the tubercle bacillus, the part played by the condition of the boty, as exemplified in general and local resistance, cannot be ignored, and it is here that injury, by reducing resistance. comes in as a possible factor in the development of the disease.

RlEFERTAC

${ }^{1}$ La Tuberculose pleuro-pulmoncure traumatique, p. 8. Paris J. B. Baillière et fils. 1915.

ACCORDING to the Journal of the Amrican Medical Association, in the new building of the Berlin Medical Society and the German Surgical Society (VirchowLangenbeck House) which was opened on April 1st, there was already installed the libiary of the Berlin Medical Society. It consists, according to the latest information, of not less than 113,163 number's, which are distributed in the following groups: 12,958 volumes of journals, 5,958 books, 6,682 dissertations and 3,226 repiints. In addition to this, there is the legacy of the Virchow library with 12,689 and the Lassar library with 1,793 volumes, and 149 bound maps with 5,000 volumes-altogether 48,501 pieces. Further, with the society are associated the libraries of some of the medical societies of Berlin with 20,757 volumes, and the library of the German Surgical Society with 44,105 volumes.

\section{THE CARRIER OF YELILOW FEVER (STEGOMYIA CALOPUS).}

\author{
BY
}

\section{A. E. SHIPLEY, Sc.D., F.R.S.} MASTER OF christ's col.LEGE, CAMBRIDGi.

\section{et nova febrium}

Terris incubuit coluors.-HORACE.

LIKE other branches of human activity disease has its romantic and its unromantic side. Nobody can regard mumps or measles as romantic. On the other hand, yellow fever calls up all the romance of slave-trading, pirates and tho Spanish Main, buccaneer's, maroonings and other' grisly horrors, whose sole redeeming feature was a touch of romance. Lovers of pirate stories-and who are not?wili always remember the graphic description of Yellow Jack in the West Indies.

We have probably always had disease with us since tho creation of the world, that act of "impardonnable impr"u. dence," as Anatole France calls it, but the fir'st description of yellow fever ouly dates back to 1647 , when an outbreak occurred in the Barbaclos. 'Then, as now, it devastated tho shipping of the port, and was soon introduced by ships into St. Christoplere and later into Guadeloupe. The following year it was in Cuba and in 1655 in Jamaica, and it gradually spread throughout the whole of the West Indies until a century or more later it reaclied St. Thomas.

One of the peculiarities of the disease is that it frequently clisappears from a given locality for lono periods of time. For instance, it was absent in the Barbados after the first ontbreak until 1690, and wlyen it recurred it was at first not recognized as being the same disease which devastated the islands forty-three years before. In tho eighteenth century there va; another break of fifty-fom year's, and similar breaks can be recorded in most of tho West Indian islands.

Besides the West Indies, it is at present enclemic in Brazil and on the West Coast of Africa, and is common in Mexico. Whother the disease arose primarily in Africa and is part of the toll the American continent has had to pay for the slave trade, or whether it was brought to tiie West Coast of Africa from the other side of the Atlantic, is not certain. It apparently appeared as a rogular clisease in Brazil in the year 1849, and from that time onwards, with the exception of one year, has been a permauent tronble at Rio. From time to time the disease has been carried to neighbouring parts of America, especially to the Gulf, Central America, and the northern coast of Sonth America. It has been introduced more than once into Monte Video and Buewos Aires, and has even penetrated up the La Plata as far as Asunçion. Every ferv years it extends into the Southern States, and has even reached Philadelphia and Boston. With the exception of an outbreak in Leghorn in 1807, European epidemics havo been confined to Portugal, Spain, and the Balearic Islands.

It will have been noticed that most of these outbrealss occur on the coast and then pass up the rivers. It is thus most probable that the dise tse is one which is brought mainly by ships. It is also obviously a disease which must be guarded against by our troops fighting near the coast in West Africa, as well as such troops as are left in the West Indies. But, above all, it must bo guarded against in relation to our shipping fleet and our navy, whose chiet naval engagcinents have hitherto been off the South American coasts.

Yellow fever is a disease which requires a winter temperature of at least $68^{\circ} \mathrm{F}$., for it is a mosquito-borise disease, and the mosquito flourishes best at about this te uperature. It can be introduced into a new locality by the arrival of an infected mos quito, or by the arrival of an infected human being. In the former case the diseas: breaks out within a few days; in the latter at least ten or twelve days elapse before new cases arise, for, as we shall see later, the organism, whatever it is, that causes tho fever is not capable of passing from the mosquito until it has been in its body for ten or twelve days.

Thirty-six years ago Finlay' of Havana suggested that the virus of yellow fever was inoculated by mosquitos; but it was not until the publication of the discoveries by Sir Ponald Ross and other's that malaria is is transferred by Anopheles that a thorough investigation 